No.4 p 39-40

\title{
Refugees in Jazovo
}

in 1992. The second stage was caused by military operations generally known as "Lighening" and "Storm" which took place in Croatia in1995. During 1995-96, 18 new refugees and expatriates came to Jazovo. According to the data given by UNHCR (1996) 27 refugees came to the village in these two stages. Only for one person they could not find out the year of arrival.

The majority of immigrants came

Bugarski, D.*

\section{Abstract}

Jazovo is a village situated in the northern part of Banat. It belongs to municipality of Coka. According to the last cebsus which was carried out in 1991, there were 1118 inhabitants there, mostly Hungarians (95,8\%).

Dangerous military operations and separation of four former Yugoslav republics (Croatia, Bosnia and Herzegovina, Slovenia and Macedonia) causedexodus of hundreds of thousands of people, mostly Serbs. The majority of them came to FR Yugoslavia i.e. its northern part Vojvodina.

Jazovoacceptedrefugeepopulation.During three stages of immigration from 1991 to1998, many families came to this village. Later, some of them moved to other places. At the beginning of May 2000, Jazovo had 30 refugee households with over 100 members. By polling 25 refugee families $(83,3 \%)$ new data were got. These families helped a loy in writing this paper which tells us about time of their arrival, origin, number, sex, age, working ability, nationality, literacy and educational level.

Key words: refugees, Jazovo

DragoljubBugarski,InstituteofGeography, University of NoviSad, YU, NoviSad, Trg Dositeja Obradovica 3 azovo is a village situated in the northern part of Yugoslav Banat. According to the administrative and regional division it belongs to municipality of Coka. After the census which had been carried out on 31.03.1931, the village had 1945 inhabitants. From that time the number of inhabitants decreases. At the time of the last census (31.03.1991) Jazovo had 1118 inhabitants. This means 827 or (42.5\%) less people than it had sixty years earlier. Depopulation is caused by the negatibe rate of population growth and migrations. The majority of inhabitants are Hungarians. At the last census, there were 1071 Hungarians or (95.8\%).

Over a hundred persons immigrated to Jazovo during the period from1991 to 1998. These were refugees and expatriates from Croatia and Bosnia and Herzegovina, i.e. from former Yugoslav republics, However, a certain number of immigtants moved later from Jazovo.

The aim of this paper is to point out the time of immigrations, number, origin and the structure of refugee population in Jazovo. For that purpose, UNHCR data from 1996 were used. The author also used the data given by the polled gefugees. The poll was carried out in April and May 2000. At that moment, Jazovo had 30 refugee households. Out of that number, 25 refugee famillies agreed to be polled.

\section{The Period of Immigrations, Number and Origin of}

\section{Immigrants}

Immigrants came to Jazovo in three stages. During the first stage i.e. the period when four former republics separated from FR Yugoslavia (Croatia, Bosnia and Herzegovina, Slovenia and Macedonia) and during the major military operations in Western Srem and Eastern Slavonia, Baranja, Bosnia and Herzegovina, 8 refugees came to Jazovo. Four of them came in 1991, the others came during the third stage from 1997 to 1998. These people came mostlybecause they could not stand the preassure to move away and whose lives and property were still in danger.

From the total number of refugees and expatriates during these three stages, certain number soon moved away from Jazovo. At the beginning of May 2000, there were 30 households with over a hundred of their members. There are data for 25 famillies who agreed to be polled.

Among these 25 famillies, members of 21 household came to Jazovo during the third stage, and only 4 households came in earlier stages.

All 25 households came from Croatia. Most of them came from Podravska Slatina region (Kusonje, Donje Kusonje, Djurisic, Popovac and Vocin). Three households came from Vukovar region (all threee from Sarengrad), three from Osijek region (two fro Dalj, one from Aljmas), two from Beli Manastir region (Beli Manastir, Knezevo) and two from Sisak region (boath from Petrinja), two from Glina region (Donje Seliste, Buzeta) and two from Zagreb (both from Zagreb). Finally, There are four more households who came from Slavonski Brod, Vuckovac, Pusine and Miljanovicevo. All of these households had 97 members at the time of the poll.

\section{Sex-Age Structure}

There is a great difference in number of male and female persons among refugee population. There are 57 or $(58,8 \%)$ female and 40 or $(41,2 \%)$ male persons.

The small number of children, only 11 , age $0-4$ and $5-9$ is caused by the negative birthrate in the current decade (1991-2000) because of the war and post-war problems. The largest number of children (12) is in the age group 15-19. It is interesting that in the age group 45-49 there is no female person, and in the age group 50-54 there is mo male person. There are less people in the age group 60 and over 60 (Table 1). 
Table 1. The structure of refugee population according to sex and age

\begin{tabular}{|l|r|r|l|r|r||}
\hline Age group & Male & Female & Age group & Male & \multicolumn{1}{|c|}{ Female } \\
\hline $0-4$ & 1 & 4 & $40-44$ & 1 & 4 \\
\hline $5-9$ & 1 & 5 & $45-49$ & 8 & - \\
\hline $10-14$ & 4 & 3 & $50-54$ & & 4 \\
\hline $15-19$ & 3 & 9 & $55-59$ & 3 & 3 \\
\hline $20-24$ & 3 & 1 & $60-64$ & 3 & 3 \\
\hline $25-29$ & 2 & 3 & $65-69$ & 1 & 3 \\
\hline $30-34$ & 5 & 6 & $70-74$ & 1 & 4 \\
\hline $35-39$ & 4 & 5 & Total & 40 & 57 \\
\hline
\end{tabular}

If the refugee population is analized according to larger age groups then there are three groups. The Young (0-19 years) 30 persons or (30,9\%). Among them there are 9 male and 21 female persons. The Middleaged (20-59) 52 persons or $(53,6 \%)$. Among them there are 26 male and 26 female persons. Finally, the Aged (60-74) 15 persons or (15,5\%).

According to the age index which is 0,50 , this population is between middle and higher raate of growing old. Though the number of young and elderly people is negative, it is still better than among native population of Jazovo. Their age index is 1,42 with high level of growing old.

There are 25 women, age 15-49,who are able to give birth. This means $49.1 \%$ of the total number of women refugees, or $28,9 \%$ of the total number of the whole refugee population in Jazovo.

\section{Economic Structure}

There are 67 refugees who are able to work. Among them, there are 32 men and 35 women, which is $69.1 \%$ of the total number of refugee population. Eleven people have permanent jobs in social services: Collective Farm "Jazovo", Fish Pond "Zlatica" near Jazovo, Meat Industry "Coka", Agricultural Plant "Coka" in Ostojicevo and in the Public Health Facility "Dr Gere Istvan" in Senta. Three people have temporary jobs in Fish Pond "Zlatica", "Menta" in Padej and Meat Industry "Coka" in Coka. Seasonal agricultural jobs have 14 people.

Five people have their own pensions. However, the number of people who received pensions in Croatia was larger. The problem of their pensions has not been solved yet, so they belong to the categoty of supported persons.
In this category of supported persons, there are 25 refigees or(25,8\%). Among them, there are 18 children and 7 elderly persons.

The relation between those who work and those who are supported is posare 2,7 working peoplr. This relation is worse among the native population. On one person there are 2,1 working people.

\section{National Structure}

The majority of refigees and expatriates are Serbs. There are 89 of them. Among them, there are 38 male and 51 female persons.

There are two Croats $(2,1 \%)$, one male and one female. Male Croat is married to a female Serb and female Croat is married to a male Serb. There are also three Russians (3,1\%). Children born in these mixed marriages decided not to belong to any national group.

\section{Literacy and Level of Education}

There are 79 refugees who are over 15 or $(81,4 \%)$. There are 76 or $(92,2 \%)$ literate persons. Only 3 or $(3,8 \%)$ persons are illiterate.

Without a single year of schooling there are 3 persons (3,8\%). With incomplete primary school ( $1-7$ years of primary school) there are 12 persons or $(15,2 \%)$. The majority of refugees finished primary school (8 years of education). Their number is 28 or $(35,4 \%)$. There are 16 or $(20,2 \%)$ persons who finished $2-3$ years of vocational secondary education. There are 15 persons (19\%) who finished secondary school (high school, medical school, school of trade). Five persons (6,3\%) finished higher schools and noone finished university. itive. On one supported person there
At the present moment, 20 persons go to school. Among them, there are 18 children who go to primary school, one goes to secondary and one to higher school.

\section{Households}

There are 7 four-member families. Then, there are 6 families that consist of three members and 4 families have 5 or 6 members. Only 3 families have 2 members and there is one family with one member. According to these data the approximate average number of family members per householdis 3,9.

There are 24 households that posses real estate(they have bought houses), while there is only one family that rents a house. There are also 7 families that have boughtfarming land.

Therefore, there are11 families who produce their own food on their farms. Others earn their living by having permanent or temporaru jobs in Jazovo, Ostojicevo, Coka, Senta and Padej. There are only five families who live on their pensions.

From time to time theserefugee families receive humanitarian aid which mostly consists of food and medicines.

\section{Conclusion}

Refugee population in Jazovo will not solve demographic problems such as: negative birthrate, migration saldo, decreasing number of people biologically reproductive,employed people, old population. This conclusion is made upon the fact of negative natural and mechanical migrations in Jazovo during the last decade (1991 - 2000). The number of inhabitants lessened for 143 from the census of 1981 to 1991. Consequently, one can expect that he number of native inhabitants will be lesser at the next census of 2001 because of very old population. This means that the refugee population will only partially improve the demographical situation in the village.

According to the poll only 8 families decided to stay permanently in Jazovo. There are 15 families who plan to move to other places in Yugoslavia, and two families intend to return to Croatia.

\section{References}

Data got by polling 25 families which was carried out in spring 2000 UNHCR, data from 1996 